\title{
Carry-over of persistent organochlorine pesticides through placenta to fetus
}

\author{
Stefan M.Waliszewski, Ph.D., (1) Angel A. Aguirre, M.Sc., (1) \\ Rosa M. Infanzón, M. Sc., (1) José Siliceo, M.Sc.(1)
}

\begin{abstract}
Waliszewski SM, Aguirre AA, Infanzón RM, Siliceo J. Carry-over of persistent organochlorine pesticides through placenta to fetus. Salud Publica Mex 2000;42:384-390.
\end{abstract}

\begin{abstract}
Objective. As a consequence of environmental exposure, organochlorine pesticides accumulate in lipid rich-tissues such as maternal adipose tissue and partition to maternal blood serum and umbilical blood serum. To establish their distribution in the human body, the concentration gradients of organochlorine pesticides between these compartments were determined. Material and methods. Maternal adipose tissue, blood serum and umbilical blood serum samples from 64 volunteers admitted for cesarean delivery at Hospital Benito Coquet Lagunes were studied in Veracruz during 1997 and 1998. The pesticide residues were determined by gas chromatography and results obtained from different sample groups were analyzed using Pearson correlation coefficients and simple lineal regression. Results. Significant results expressed on fat basis of organochlorine pesticides indicate that I, I, I-trichloro-2,2-bis(4-chlorophenyl)ethane (DDT) levels are higher in maternal adipose tissue $(4.5 \mathrm{I} \mathrm{mg} / \mathrm{kg}$ DDE and $1.27 \mathrm{mg} / \mathrm{kg}$ pp'DDT), maternal blood serum (4.45 mg/kg DDE and $0.78 \mathrm{mg} / \mathrm{kg}$ Pp'DDT), and umbilical blood serum $(4.70 \mathrm{mg} / \mathrm{kg}$ DDE and $0.88 \mathrm{mg} /$ $\mathrm{kg}$ PP'DDT), due to greater affinity of DDT for lipids. Conclusions. The statistical evaluation of results and the pairing of samples analyzed indicate that absorbed organochlorine pesticides cross the placental barrier and reach a balanced state between mother and fetus.
\end{abstract}

Key words: xenoestrogens; placental barrier; uteroplacental circulation; pesticides; Mexico

\author{
Waliszewski SM, Aguirre AA, Infanzón RM, Siliceo J. \\ Paso de los plaguicidas organoclorados \\ persistentes a través de placenta al feto. \\ Salud Publica Mex 2000;42:384-390.
}

\section{Resumen}

Objetivo. Como consecuencia de la exposición ambiental a los plaguicidas organoclorados éstos se acumulan en tejidos ricos en grasa, como el adiposo materno, y se distribuyen en el suero materno y el suero del cordón umbilical. Para establecer la distribución en el organismo humano, se comparó el gradiente de concentración de los plaguicidas organoclorados entre estos compartimentos. Material y métodos. Se tomaron las muestras de tejido adiposo materno, suero materno y suero del cordón umbilical de 64 participantes voluntarias admitidas para cesárea en el Hospital Benito Coquet Lagunes, de la ciudad de Veracruz, Veracruz, México, durante el periodo 1997-1998. Los residuos de plaguicidas se determinaron por cromatografía de gases y sus resultados se correlacionaron entre las muestras por medio del coeficiente de correlación de Pearson y regresión lineal simple. Resultados. Los resultados más significativos expresados en base lipídica indican que las concentraciones del DDT fueron más altas en el tejido adiposo materno $(4.5 \mathrm{I} \mathrm{mg} / \mathrm{kg}$ DDE y $1.27 \mathrm{mg} / \mathrm{kg}$ Pp'DDT), suero materno ( $4.45 \mathrm{mg} / \mathrm{kg}$ DDE y $0.78 \mathrm{mg} / \mathrm{kg}$ pp'DDT) y suero del cordón umbilical ( $4.70 \mathrm{mg} / \mathrm{kg}$ DDE y $0.88 \mathrm{mg} / \mathrm{kg}$ Pp'DDT), debido a su mayor afinidad a los lípidos. Conclusiones. La evaluación estadística de los resultados y el pareado entre las muestras indican que los plaguicidas organoclorados absorbidos atraviesan la barrera placentaria y forman un equilibrio entre el organismo materno y el feto.

Palabras clave: xenoestrógenos; barrera placentaria; circulación uteroplacentaria; plaguicidas; México

This study was supported by Mexico's National Council for Science and Technology (Conacyt) grant 4238 P-M.

(I) Instituto de Medicina Forense de la Universidad Veracruzana.Veracruz,Ver., México.

Received on: March 8, 2000 - Accepted on: July 27, 2000

Reprint requests to: Dr. Stefan M.Waliszewski. Instituto de Medicina Forense de la Universidad Veracruzana. SS Juan Pablo II esq. Reyes Heroles, Boca del Río, 94290 Veracruz, México.

E-mail: stefanmw@vice-ver.veracruz.uv.mx 
$\mathbf{S}$ ince their introduction in agriculture and public health, persistent organochlorine pesticides, such as 1,1,1-trichloro-2,2-bis(4-chlorophenyl)ethane (DDT) and hexachlorocyclohexane $(\mathrm{HCH})$, have provided great benefits to humans. Their intensive use throughout decades has raised the interest in knowing the extent of their spread, leading to investigations of the magnitude of their residues in all elements of the human environment. ${ }^{1}$ Investigations involving possible health and environmental hazards, have led governments of many countries to ban DDT, or to restrict the minimum accepted values of their residues in foodstuffs. In the 1980's, banned DDT reappeared, being recommended by $\mathrm{WHO}^{2}$ as the pesticide of choice in the combat of malaria vectors susceptible to DDT in tropical areas. ${ }^{3}$

In tropical countries like Mexico, the extensive use of organochlorine pesticides in sanitary actions has great implications regarding their persistence in the environment and subsequent human contamination. ${ }^{4,5}$ DDT is useful in sanitation as the insecticide of choice in the combat of susceptible malaria vectors. ${ }^{6}$ Because of DDT's volatility and widespread propagation, the main route of human exposure in tropical areas consists of inhalation of contaminated air. ${ }^{78}$ An alternative route of human exposure consists of consumption of contaminated food, especially food of animal origin. ${ }^{9,10}$ Organochlorine pesticides, due to their lipophilic nature and high persistence, accumulate in food chains and in the human body, especially in lipid-rich tissues, such as adipose tissue. The presence of organochlorine pesticide residues in human adipose tissue has recently caused concern due to their antiandrogenic and estrogenic properties and their effects on sexual activity and development of breast cancer.,11-13 The contamination rate of tropical area inhabitants depends mainly on individual accumulation. This is influenced by local environmental pollution, diet, duration of exposure, age, capacity for elimination by metabolism, and number of nursed infants. ${ }^{14-20}$ Moreover, the monitoring of human tissues could be used as an indicator for understanding the biological specificity in the accumulation of organochlorine pesticides in the tropical environment, as well as for assessing their participation in environmental pollution. ${ }^{21}$

The aims of the present study are two: a) to compare the concentrations of selected organochlorine pesticides in maternal adipose tissue, maternal blood serum, and umbilical blood serum, as a consequence of environmental exposure to these pesticides in tropical areas of Mexico, due to their spraying in the combat of vector-transmitted diseases; and b) to correlate their concentration gradients among human body matrices.

salud pública de méxico / vol.42, no.5, septiembre-octubre de 2000

\section{Material and methods}

\section{Study design}

In the study, sixty-four volunteer mothers among patients admitted for cesarean delivery to Social Security Hospital Benito Coquet Lagunes in Veracruz during 1997-1998, were chosen to participate. Volunteers who signed consent, were selected from those who had lived for at least one year in Veracruz or its suburban zone and had not presented additional disorders. Approximately $5 \mathrm{~g}$ of adipose tissue from the abdominal cavity and umbilical blood serum samples were obtained during cesarean sections. Maternal blood samples of approximately $10 \mathrm{ml}$ were collected from fasting participants by venipuncture, two days before cesarean section and the serum was separated by centrifugation. For organochlorine pesticide analysis, the sample constituted the remaining portion of blood serum taken for routine clinical analysis.

\section{Chemical analysis}

Adipose tissue and blood serum samples were analyzed according to previously described methods. ${ }^{22-24}$ The qualitative and quantitative determinations were done by gas chromatography on a Varian 3400 CX apparatus equipped with a ${ }^{63} \mathrm{Ni}$ electron capture detector. A volume of $1 \mu \mathrm{l}$ was injected in splitless mode into a PTE-5 QTM $15 \mathrm{~m} \times 0.53 \mathrm{~mm}$ id. $0.5 \mu \mathrm{m}$ film capillary column, using nitrogen as carrier gas with a 6.7 $\mathrm{ml} / \mathrm{min}$ flow rate and the following temperature program: $140{ }^{\circ} \mathrm{C}(3 \mathrm{~min})$ to $250{ }^{\circ} \mathrm{C}$ at $10{ }^{\circ} \mathrm{C} / \mathrm{min}$, hold 10 $\mathrm{min}$. The temperatures of the detector and injector were $320^{\circ} \mathrm{C}$ and $220{ }^{\circ} \mathrm{C}$, respectively.

All of the samples were analyzed for: $\mathrm{HCB}, \alpha, \beta, \gamma-$ $\mathrm{HCH}$, Aldrin, Heptachlor, Heptachlor epoxide, $\mathrm{pp}^{\prime} \mathrm{DDT}$, op'DDT, $\mathrm{pp}^{\prime} \mathrm{DDE}, \mathrm{pp}^{\prime} \mathrm{DDD}, \alpha, \beta$-Endosulfans and Endosulfan sulfate. Chlordane and its isomers, Dieldrin and Methoxychlor were degraded during clean-up of extracts with concentrated sulfuric acid. The minimum detection limits expressed on fat basis for the organochlorine pesticides studied were: 0.001 $\mathrm{mg} / \mathrm{kg}$ for $\mathrm{HCB}$ and $\mathrm{HCH}$ isomers, $0.002 \mathrm{mg} / \mathrm{kg}$ for Aldrin, Heptachlor, Heptachlor epoxide and pp'DDE, and $0.003 \mathrm{mg} / \mathrm{kg}$ for $\mathrm{pp}^{\prime} \mathrm{DDT}$, op'DDT, pp'DDD and Endosulfans. To determine the quality of the method, the recovery study was performed on ten overspiked replicates of a blank cow blood serum sample and a blank cow fat sample, which revealed contamination levels below detection limits. The fortification study, done at 0.005 to $0.020 \mathrm{mg} / \mathrm{kg}$ levels, depending on the pesticide, showed mean values from $89 \%$ to $95 \%$ of recovery (except $\alpha$ and $\beta$-Endosulfans, caused by the par- 
tial conversion of $\alpha$-Endosulfan to $\beta$-Endosulfan under the influence of concentrated sulfuric acid during the clean-up step). The standard deviation and coefficient of variation were below 10, indicating excellent repeatability of the method.

Total serum lipids were determined colorimetrically with phosphovanillin according to the method recommended by Wiener Lab for clinical laboratories.

\section{Statistical analysis}

Organochlorine pesticide residue mean values in blood serum and adipose tissue were calculated using basic statistics. To compare variability among body matrices, the Pearson correlation coefficients $\left(r, r^{2}\right)$ and simple linear regression coefficients were calculated using the statistical software Minitab 12.

\section{Results}

In all analyzed samples the presence of Aldrin, Heptachlor, Heptachlor epoxide, $\alpha, \beta$-Endosulfan and Endosulfan sulfate was not detected and thus they are excluded from further discussion.

Samples taken from maternal adipose tissue, maternal blood serum, and umbilical cord blood serum from 64 mothers, were analyzed to confirm concentration levels in both sizes of organisms (mother and fetus). The obtained results of determinations and the statistical calculations are presented in Tables I and II, as frequencies, arithmetic means, medians, and quartiles. The highest frequencies $(100 \%)$ correspond to $\mathrm{HCB}, \beta-\mathrm{HCH}$ and $\mathrm{pp}^{\prime} \mathrm{DDE}$, especially in adipose tissue. A $100 \%$ frequency of $\mathrm{pp}^{\prime} \mathrm{DDE}$ is presented in all analyzed samples of maternal adipose tissue, maternal blood serum, and umbilical cord blood serum. Likewise, the $p^{\prime} \mathrm{DDE}$ is a dominant pesticide with its highest levels determined in adipose tissue at 4.51 $\mathrm{mg} / \mathrm{kg}$, in maternal blood serum at $4.45 \mathrm{mg} / \mathrm{kg}$, and in umbilical cord blood serum at $4.70 \mathrm{mg} / \mathrm{kg}$, indicating that lipid-rich tissues are in equilibrium among these body compartments. The observed differences among the other organochlorine pesticides depend on the lipophility of the pesticide and their physical-chemical properties, which govern its behavior and specific accumulation in the organism. A similar tendency is expressed by the more persistent compounds pp'DDT $(1.27 \mathrm{mg} / \mathrm{kg}$ of maternal adipose tissue, $0.78 \mathrm{mg} / \mathrm{kg}$ of maternal blood serum, and $0.88 \mathrm{mg} / \mathrm{kg}$ of umbilical blood serum), and $\beta-\mathrm{HCH}(0.16 \mathrm{mg} / \mathrm{kg}$ of maternal adipose tissue, $0.20 \mathrm{mg} / \mathrm{kg}$ of maternal blood serum and $0.22 \mathrm{mg} / \mathrm{kg}$ of umbilical blood serum). Generally, the pesticides stored in adipose tissue are liberated to the blood serum, according to their partitioning coefficients and their physical-chemical properties, which are characteristic for each compound.

The lowest frequencies corresponded to isomers $\alpha-$ and $\gamma-\mathrm{HCH}$, op'DDT and pp'DDD in adipose tis-

Table I

HCB AND HCH'S COMPARISON OF FREQUENCIES, MEAN VALUES, MEDIANS, AND QUARTILES OF RESULTS (MG/KG ON FAT BASIS) FROM SAMPLES OF MATERNAL ADIPOSE TISSUE, MATERNAL BLOOD SERUM,

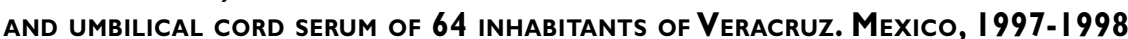

\begin{tabular}{lcllll} 
Pesticide & Frequency (\%) & Mean & Median & QI & Q3 \\
HCB adipose & 100 & 007 & 0.05 & 0.04 & 0.08 \\
\hline $\mathrm{HCB}$ serum & 100 & 0.18 & 0.16 & 0.12 & 0.22 \\
\hline $\mathrm{HCB}$ umbilical & 98 & 0.29 & 0.25 & 0.16 & 0.38 \\
\hline$\alpha-\mathrm{HCH}$ adipose & 36 & 0.01 & 0 & 0 & 0.01 \\
\hline$\alpha-\mathrm{HCH}$ serum & 14 & 0.01 & 0 & 0 & 0 \\
\hline$\alpha-\mathrm{HCH}$ umbilical & 14 & 0.01 & 0 & 0 & 0.08 \\
\hline$\beta-\mathrm{HCH}$ adipose & 100 & 0.16 & 0.11 & 0 & 0.32 \\
\hline$\beta-\mathrm{HCH}$ serum & 72 & 0.20 & 0.16 & 0 & 0.35 \\
\hline$\beta-\mathrm{HCH}$ umbilical & 61 & 0.22 & 0.16 & 0 & 0.01 \\
\hline$\gamma-\mathrm{HCH}$ adipose & 63 & 0.01 & 0.01 & 0 & 0.01 \\
\hline$\gamma-\mathrm{HCH}$ serum & 25 & 0.01 & 0 & 0 & 0 \\
\hline$\gamma-\mathrm{HCH}$ umbilical & 14 & 0.01 & 0.12 & 0.08 & 0.18 \\
\hline$\sum-\mathrm{HCH}$ adipose & 0.17 & 0.22 & 0.18 & 0 & 0.38 \\
\hline$\sum-\mathrm{HCH}$ serum & 0.24 & 0.16 & 0 & 0.42
\end{tabular}


Table II

DDT'S COMPARISON OF FREQUENCIES, MEAN VALUES, MEDIANS, AND QUARTILES OF RESULTS (MG/KG ON FAT BASIS) FROM SAMPLES OF MATERNAL ADIPOSE TISSUE, MATERNAL BLOOD SERUM, AND UMBILICAL CORD SERUM OF 64 INHABITANTS OF VERACRUZ. MEXICO, I 997 - 1998

\begin{tabular}{|c|c|c|c|c|c|}
\hline Pesticide & Frequency (\%) & Mean & Median & QI & Q3 \\
\hline DDE adipose & 100 & 4.51 & 4.08 & 1.68 & 6.40 \\
\hline DDE serum & 100 & 4.45 & 3.66 & 1.55 & 5.97 \\
\hline DDE umbilical & 100 & 4.70 & 4.06 & 1.70 & 6.22 \\
\hline DDD adipose & 31 & 0.03 & 0 & 0 & 0.01 \\
\hline DDD serum & 3 & 0.01 & 0 & 0 & 0 \\
\hline DDD umbilical & 0 & 0 & 0 & 0 & 0 \\
\hline op'DDT adipose & 86 & 0.06 & 0.04 & 0.01 & 0.07 \\
\hline op'DDT serum & 13 & 0.04 & 0 & 0 & 0 \\
\hline op'DDT umbilical & 8 & 0.03 & 0 & 0 & 0 \\
\hline Pp'DDT adipose & 98 & 1.27 & 0.34 & 0.17 & 1.28 \\
\hline Pp'DDT serum & 42 & 0.78 & 0 & 0 & 0.62 \\
\hline Pp'DDT umbilical & 31 & 0.88 & 0 & 0 & 0.72 \\
\hline$\sum$-DDT adipose & & 5.86 & 4.63 & 1.94 & 8.03 \\
\hline$\sum$-DDT serum & & 5.26 & 4.05 & 1.54 & 6.61 \\
\hline$\sum$-DDT umbilical & & 5.59 & 4.73 & 1.81 & 7.30 \\
\hline
\end{tabular}

sue and blood serum samples. These lower values are caused by less exposure to Lindane $(\gamma-\mathrm{HCH})$ and diminished use of DDT in applications to combat malaria vectors. Thus, a lower level of pp'DDD was determined in the human body, which we considered an indicator of recent $\mathrm{pp} \mathrm{p}^{\prime} \mathrm{DDT}$ exposure, since $\mathrm{pp} \mathrm{PDD}^{\prime} \mathrm{DD}$ is determined in the human body only for a short period immediately after DDT application.

Tables III and IV present the Pearson correlation coefficients $(r)$ of paired organochlorine pesticide levels among matrices studied, as well as correlation coefficients squared $\left(r^{2}\right)$ and regression coefficients $(\beta)$, to express the magnitude of the correlations. These coefficients indicate the degree of linear relationship between the two matrices studied; higher values express a positive correlation among adipose tissue, maternal blood, and umbilical cord blood. Higher and consistent values were found among matrices studied, which represent adipose tissue and maternal blood serum, as well as maternal blood serum and umbilical cord blood serum. Among pesticides studied, the higher values reveal that the more persistent compounds were $\mathrm{HCB}$ in adipose tissue - maternal blood serum $(r=0.97$ and $\beta=0.52), \beta-\mathrm{HCH}$ maternal blood serum - umbilical cord blood serum ( $r=0.86$ and $\beta=0.68)$, pp'DDE adipose tissue - maternal blood serum $(r=0.92$ and $\beta=0.93)$ and serum $(r=0.84$ and $\beta=0.64)$. pp'DDT maternal blood serum - umbilical cord blood

\section{Table III}

Paired Pearson correlation and regression COEFFICIENTS OF HCB AND HCH'S RESULTS

(MG/KG ON FAT BASIS) OF MATERNAL ADIPOSE TISSUE, MATERNAL BLOOD SERUM, AND UMBILICAL BLOOD SERUM FROM 64 INHABITANTS OF VERACRUZ. MeXICO, I997-1998

Pesticide

$\begin{array}{ccc} & \text { Pearson } \\ \text { Pearson } & \text { correlation } & \text { Regression } \\ \text { correlation } & \text { coefficient } & \text { coefficients } \\ \text { coefficient }(r) & \text { squared }\left(r^{2}\right) & (\beta)\end{array}$

\begin{tabular}{llll} 
HCB adipose $-\mathrm{HCB}$ serum & 0.97 & 0.94 & 0.34 \\
\hline $\mathrm{HCB}$ adipose $-\mathrm{HCB}$ umbilical & 0.80 & 0.64 & 0.18 \\
\hline $\mathrm{HCB}$ serum $-\mathrm{HCB}$ umbilical & 0.83 & 0.69 & 0.52 \\
\hline$\alpha-\mathrm{HCH}$ adipose $-\alpha-\mathrm{HCH}$ serum & $0.5 \mathrm{I}$ & 0.26 & 0.20 \\
\hline$\alpha-\mathrm{HCH}$ adipose $-\alpha-\mathrm{HCH}$ umbilical & 0.49 & 0.24 & 0.15 \\
\hline$\alpha-\mathrm{HCH}$ serum $-\alpha-\mathrm{HCH}$ umbilical & 0.98 & 0.96 & 0.78 \\
\hline$\beta-\mathrm{HCH}$ adipose $-\beta-\mathrm{HCH}$ serum & 0.56 & 0.32 & 0.63 \\
\hline$\beta-\mathrm{HCH}$ adipose $-\beta-\mathrm{HCH}$ umbilical & 0.56 & $0.3 \mathrm{I}$ & 0.50 \\
\hline$\beta-\mathrm{HCH}$ serum $-\beta-\mathrm{HCH}$ umbilical & 0.86 & 0.74 & 0.68 \\
\hline$\gamma-\mathrm{HCH}$ adipose $-\gamma-\mathrm{HCH}$ serum & 0.33 & $0.1 \mathrm{I}$ & 0.15 \\
\hline$\gamma-\mathrm{HCH}$ adipose $-\gamma-\mathrm{HCH}$ umbilical & 0.25 & 0.06 & 0.09 \\
\hline$\gamma-\mathrm{HCH}$ serum $-\gamma-\mathrm{HCH}$ umbilical & 0.62 & 0.38 & 0.46 \\
\hline$\sum-\mathrm{HCH}$ adipose $-\sum-\mathrm{HCH}$ serum & 0.55 & 0.30 & 0.58 \\
\hline$\sum-\mathrm{HCH}$ adipose $-\sum-\mathrm{HCH}$ umbilical & 0.56 & 0.32 & 0.48 \\
\hline$\sum-\mathrm{HCH}$ serum $-\sum-\mathrm{HCH}$ umbilical & 0.87 & 0.75 & 0.71
\end{tabular}


Table IV

Paired Pearson correlation and regression COEFFICIENTS OF DDT'S RESULTS (MG/KG ON FAT BASIS)

OF ADIPOSE TISSUE, BLOOD SERUM, AND UMBILICAL BLOOD SERUM, FROM 64 INHABITANTS OF VERACRUZ. Mexico, 1997-1998

\begin{tabular}{llll} 
Pesticide & $\begin{array}{c}\text { Pearson } \\
\text { correlation } \\
\text { coefficient }(r)\end{array}$ & $\begin{array}{c}\text { Pearson } \\
\text { correlation } \\
\text { coefficient } \\
\text { squared }\left(r^{2}\right)\end{array}$ & $\begin{array}{c}\text { Regression } \\
\text { coefficients } \\
(\beta)\end{array}$ \\
DDE adipose - DDE serum & 0.92 & 0.85 & 0.85 \\
\hline DDE adipose - DDE umbilical & 0.88 & 0.77 & 0.88 \\
\hline DDE serum - DDE umbilical & 0.85 & 0.73 & 0.93 \\
\hline DDD adipose - DDD serum & - & - & - \\
\hline DDD adipose- DDD umbilical & - & - & - \\
\hline DDD serum - DDD umbilical & - & - & - \\
\hline op'DDT adipose - op'DDT serum & 0.19 & 0.04 & 0.09 \\
\hline op'DDT adipose - op'DDT umbilical & 0.13 & 0.02 & 0.08 \\
\hline op'DDT serum - op'DDT umbilical & 0.93 & 0.86 & 1.07 \\
\hline Pp'DDT adipose - pp'DDT serum & 0.73 & 0.53 & 0.84 \\
\hline Pp'DDT adipose - pp'DDT umbilical & 0.60 & 0.36 & 0.52 \\
\hline Pp'DDT serum - pp'DDT umbilical & 0.84 & 0.71 & 0.64 \\
\hline$\sum$-DDT adipose - $\sum$-DDT serum & 0.90 & 0.81 & 0.82 \\
\hline$\sum$-DDT adipose - $\sum$-DDT umbilical & 0.81 & 0.66 & 0.76 \\
\hline$\sum$-DDT serum - $\sum$-DDT umbilical & 0.87 & 0.76 & 0.89
\end{tabular}

\section{Discussion}

The assumption of chemical equilibrium for deposition of persistent organochlorine pesticides in the human body during pregnancy implies chemical transport from maternal tissues to the fetus through the passive transport processes and equilibrium between pesticide concentrations in maternal tissues and fetus. ${ }^{25,26}$ This equilibrium permits a rapid internal distribution of persistent organochlorine pesticides within the organism. These pesticides are quantified as uniform among maternal tissues when the determinations are expressed on fat basis. 27,28 Pregnancy involves the transfer of lipids and lipoproteins from maternal tissues through placenta to fetus. This process results in carry-over of persistent organochlorine pesticides through the placenta and their presence in lipid-rich tissues of the fetus. The subsequent metabolic transformation in the fetus is low, due to poor enzymatic activity in the developing organism.

Since persistent organochlorine pesticides largely reside in lipids and the lipid solubility of organochlorine pesticides does not differ substantially among various lipids of the human body, the equilibrium between mother and fetus can be defined as chemical fugacities in maternal tissues and fetus. Thus, it can be assumed that the apparently equal concentrations in both sizes of organisms, (for example, DDT total: adipose tissue $5.86 \mathrm{mg} / \mathrm{kg}$, maternal serum $5.26 \mathrm{mg} / \mathrm{kg}$, and umbilical cord serum $5.59 \mathrm{mg} / \mathrm{kg}$ on fat basis,) depend on the lipid content of tissues. ${ }^{25}$

The analyses of paired groups of maternal adipose tissue, maternal blood serum, and umbilical cord blood serum, show that the frequency and mean values determined in maternal blood serum and umbilical cord serum are very similar. Median values reveal a greater similarity of pesticide levels between maternal adipose tissue and umbilical cord blood serum, for example, DDT total: $4.63 \mathrm{mg} / \mathrm{kg}$ in maternal adipose tissue and $4.73 \mathrm{mg} / \mathrm{kg}$ in umbilical cord serum. This finding can be explained by the equilibrium and partial retention of these pesticides in the fetus, with little possibility for them to return to the maternal bloodstream through the placenta.

To assess the relationships of organochlorine pesticide concentrations among maternal adipose tissue, maternal blood serum, and umbilical cord blood serum, values were paired and analyzed using the Pearson correlation coefficient $(r)$ and the Pearson correlation factor squared $\left(r^{2}\right)$ (Tables III and IV). The correlation values are consistent with the previous observations of Kutz et al ${ }^{29}$ and Duarte-Davidson et al..$^{30,31}$ They indicate that diversity between paired groups depends principally on the physical-chemical properties of each organochlorine pesticide and compartment composition, shown by the levels presented in the tables; such properties permit an equilibrium among compartments and their specific accumulation. Generally, the highest correlation can be observed between maternal blood serum and umbilical cord blood serum, indicating an equilibrium pattern between these body compartments.

Table V presents the comparison of selected persistent organochlorine pesticide levels in human adipose tissue reported in different countries. ${ }^{32-37}$ Comparisons show that levels of pesticides determined in this study are in the same range as those from other countries, including levels determined in Greenland ${ }^{37}$ In tropical countries, like Mexico, DDT has been used by the Secretary of Health in the combat of vector-transmitted diseases, an action that causes their dispersion in the human environment. Recently, DDT use has been restricted in Mexico, leading to a decrease in DDT exposure and human contamination.

In conclusion, it can be pointed out that the organochlorine pesticides absorbed by pregnant women are distributed almost uniformly in the bloodstream of the maternal organism and pass through the placenta 
Table V

\section{Comparison OF PERSISTENT ORgANOCHLORINE PESTICIDE LEVELS (MG/KG ON FAT BASIS) IN HUMAN ADIPOSE TISSUE AMONG DIFFERENT COUNTRIES}

\begin{tabular}{|c|c|c|c|c|c|c|c|}
\hline Pesticide & Kenya 199232 & Poland $1994^{33}$ & Italy $1995^{34}$ & Spain $1995^{35}$ & Iran $1995^{36}$ & Greenland 199937 & This study \\
\hline $\mathrm{HCB}$ & - & 0.31 & - & 3.37 & 0.06 & - & 0.07 \\
\hline$\beta-\mathrm{HCH}$ & 0.03 & 0.23 & 0.21 & 1.53 & 0.73 & 0.11 & 0.16 \\
\hline Pp'DDE & 3.26 & 5.75 & 0.40 & 3.93 & 2.45 & 3.19 & 4.51 \\
\hline Pp'DDT & 2.49 & 0.54 & 0.06 & 0.40 & 0.19 & 0.14 & 1.27 \\
\hline
\end{tabular}

to the developing fetus, where they accumulate in the lipid-rich tissues and form the first contamination source for the developing organism. Due to the estrogenic and antiandrogenic activity of DDTs, their passage through the placenta and the subsequent fetal exposure can be considered a risk factor to the fetus, which can contribute to congenital malformations of external genitalia. The obtained correlations confirm that the placenta does not retain small molecules dissolved in blood serum components, such as organochlorine pesticides, and explain our previous determination of $102 \mathrm{mg} / \mathrm{kg}$ of total DDT detected in adipose tissue obtained during the autopsy of a still-born baby. ${ }^{38}$

\section{References}

I. López-Carrillo L,Torres-Arreola L,Torres-Sánchez L, Espinosa-Torres F, Jiménez $C$, Cebrian $M$ et al. Is DDT use a public health problem in Mexico? Environ Health Perspect 1996; 104:584-588.

2. World Health Organization. Chemical methods for the control of arthropod vectors and pests of public health importance. Ginebra:WHO, 1984.

3. Pan American Health Organization. Pan American Health Organization, XLII Report 1995.

4.Waliszewski SM, PardioVTS, Chantiri JNP, Infanzón RMR, Rivera J. Organochlorine pesticide residues in adipose tissue of Mexicans. Sci Total Environ 1996;|81:|25-131.

5. Waliszewski SM, Aguirre AA, Infanzón RM, Rivera J, Infanzón R. Time trend of organochlorine pesticide residues in human adipose tissue in Veracruz, Mexico: 1988-1997 survey. Sci Total Environ 1998;221:201-204. 6. Gutiérrez-Samperio M, Trujillo-Arriaga J, Ramírez-y Ramírez F, VélezMéndez A. Catálogo Oficial de Plaguicidas. México, D.F:: Cicoplafest, 1994. 7. Jury WA, Spencer WF, Farmer WJ. Use of models for assessing relative volatility, mobility and persistence of pesticides and other trace organics in soil systems. En: Spencer W, ed. Hazard assessment of chemicals. San Diego:Academic Press 1982;2: I-43.

8. Mathies M, Behrendt H, Trapp S. Modeling and model validation for exposure assessment of the terrestrial environment. En: Frese $\mathrm{H}$, ed. Pesticide chemistry. Nueva York:Verlag Chemie, 1991:433-444.

9. Waliszewski SM, Infanzón RM, Rivera J. Levels of organochlorine pesticides in bovine kidney fat. Fresenius Environ Bull 1995;4:342-345.

10. Waliszewski SM, Pardio VT, Waliszewski KN, Chantiri JN, Aguirre AA, Infanzón RM, Rivera J. Time tendency of organochlorine pesticide resi- dues in cow's milk from agricultural regions of Veracruz (Mexico). Fresenius Environ Bull 1998;7:238-243.

II.Wolff MS. Pesticides - how research has succeeded and failed in forming policy: DDT and the link with breast cancer. Environ Health Perspect 1995; 103 (suppl 6):87-91.

12. Ahlborg UG, Lipworth L, Titus-Ernstoff L, Hsieh C-C, Hanberg A, Baron $\mathrm{J}$ et al. Organochlorine compounds in relation to breast cancer, endometrial cancer, and endometriosis: An assessment of the biological and epidemiological evidence. Crit Rev Toxicol 1995;25:463-53I.

13. Hunter DJ, Hankinson SE, Laden F, Colditz GA, Manson JE, Willett WC et al. Plasma organochlorine levels and the risk of breast cancer. N Engl J Med 1997;337:1253-1258.

14. Noren K. Contemporary and retrospective investigations of human milk in the trend studies of organochlorine contaminants in Sweden. Sci Total Environ 1993; 139/140:347-355.

I5. Bordet F, Mallet J, Maurice L, Borrel S, Venant A. Organochlorine pesticide and PCB congener content of French human milk. Bull Environ Contam Toxicol 1993;50:425-432.

16. Brunetto R, Leon A, Burguera JL, Burgurera M. Levels of DDT residues in human milk of Venezuelan women from various rural populations. Sci Total Environ 1996; 186:203-207.

17. Czaja K, Ludwicki JK, Góralczyk K, Strucinski P. Effect of age and number of deliveries on mean concentration of organochlorine compounds in human breast milk in Poland. Bull Environ Contam Toxicol 1997;59: 407-4I3.

18. Waliszewski SM, Aguirre AA, Infanzón RM, Rivera J, Infanzón R. Levels of organochlorine pesticide residues in human milk from mothers living in Veracruz, Mexico. Fresenius Environ Bull 1998;7:709-716.

19. Smith D.Worldwide trends in DDT levels in human breast milk. Intern J Epidemiol 1999;28:179-188.

20. Laden F, Neas LM, Spiegelman D, Hankinson SE, Willett WC, Ireland K et al. Predictors of plasma concentrations of DDE and PCBs in a group of U.S. women. Environ Health Perspect 1999;107:75-81.

21. Tanabe S, Gondaira F, Subramanian A, Ramesh A, Mohan D, Kumaran P et al.Specific pattern of persistent organochlorine residues in human breast milk from South India. J Agric Food Chem 1990;38:899-903.

22. Waliszewski SM, Szymczynski GA. Simple, low-cost method for determination of selected chlorinated pesticides in fat samples. J AOAC Int 1982;65:677-679.

23.Waliszewski SM, Szymczynski GA. Persistent organochlorine pesticides in blood serum and whole blood. Bull Environ Contam Toxicol 1991;46: 803-809.

24.Waliszewski SM,Aguirre AA, Benítez A, Infanzón RM, Infanzón R, Rivera J. Organochlorine pesticide residues in human blood serum of inhabitants of Veracruz, Mexico. Bull Environ Contam Toxicol 1999;62:397-402.

25. Russell RW, Gobas FAPC, Haffner GD. Maternal transfer and in ovo exposure of organochlorines in oviparous organism: A model and field verification. Environ Sci Technol 1999;33:416-420. 
26. Rhainds M, Levallois P, Dewailly E,Ayotte P. Lead, mercury and organochlorine compound levels in cord blood in Quebec, Canada.Arch Environ Health 1999; 54: 40-47.

27. Mes J. Organochlorine residues in human blood and biopsy fat and their relationship. Bull Environ Contam Toxicol 1992;48:815-820.

28. Parham FM, Kohn MC, Matthews HB, DeRosa C, Portier CJ. Using structural information to create physiologically based pharmacokinetic models for all polychlorinated biphenyls. I. Tissue: Blood partition coefficients. Toxicol Appl Pharmacol 1997; 144:340-347.

29. Kutz FW, Yobs AR, Strassman SC. Organochlorine pesticide residues in human adipose tissue. Bull Soc Pharmacol Environ Pathol 1976;4:17-19. 30. Duarte-Davidson R, Allen SC, Jones KC. PCBs and other organochlorines in human adipose tissue from the Welch population. I.Adipose. Environ Pollut 1994;84:69-77.

3I. Duarte-Davidson R, Wilson SC, Jones KC. PCBs and other organochlorines in human adipose tissue from the Welch population. I. Milk. Environ Pollut 1994;84:79-87.

32. Kanja LW, Skaare JU, Ojwang SBO, Maitai CK.A comparison of organochlorine pesticide residues in maternal adipose tissue, maternal blood, cord blood, and human milk form mother/infant pairs. Arch Environ Contam Toxicol 1992;22:21-24.
33. Ludwicki JK, Góralczyk K. Organochlorine pesticides and PCBs in human adipose tissue in Poland. Bull Environ Contam Toxicol 1994;52: 400-403.

34. Gallelli G, Mangini S. Organochlorine residues in human adipose and hepatic tissues from autopsy sources in Northern Italy. J Toxicol Environ Health 1995;46:293-300.

35. Gómez-Catalán J, Lezaun M, To-Figueras J, Corbella J. Organochlorine residues in the adipose tissue of the population of Navarra (Spain). Bull Environ Contam Toxicol 1995;54:534-540.

36. Burgaz S, Afkham BL, Karakaya AE. Organochlorine pesticide contaminants in human adipose tissue collected in Tebriz (Iran). Bull Environ Contam Toxicol 1995; 54: 546-553.

37. Dewailly E, Mulvad G, Pedersen HS, Ayotte P, Demers A, Weber J-P et al. Concentration of organochlorines in human brain, liver, and adipose tissue autopsy samples from Greenland. Environ Health Perspect 1999;107(I0):823-828.

38. Waliszewski SM, Pardio VT, Chantiri JN, Aguirre AA. Organochlorine pesticide body burden of young Mexicans. 1994 survey. Fresenius Environ Bull 1996;5:357-360. 